JAMP: Jurnal Adminitrasi dan Manajemen Pendidikan

Volume 3 Nomor 3 September 2020, Hal : 224-232

Tersedia Online di http://journal2.um.ac.id/index.php/jamp/

ISSN 2615-8574 (online)

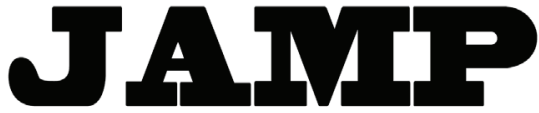

JURNAL ADMINISTRASI DAN MANAJEMEN PENDIDIKAN

\title{
MANAJEMEN PROGRAM PUTRA PUTRI BERKARAKTER DI SEKOLAH MENENGAH ATAS
}

\author{
Maharina Emiliya Yunita \\ Achmad Supriyanto \\ Desi Eri Kusumaningrum
}

\author{
Universitas Negeri Malang Jl. Semarang No 5 Malang 65145 \\ sayarina15@gmail.com, a.supriyanto.fip@um.ac.id,desi.eri.fip@um.ac.id
}

\begin{abstract}
The Character Building Program is very important so that education management can function. The purpose of this study is to describe the activities of planning, organizing, implementing, evaluating, coordinating, and characterizing the Putra Putri Character program. This study uses qualitative research with case study type. The process of collecting data used by researchers is observation, interviews, and documentation. In data analysis, research conducts data collection, condensation data, data presentation, and conclusion collection. The conclusions of this study are (1) program planning produces schedules and provisions, (2) organizing programs produce organizational structures, (3) implementation programs complete written tests, interview tests, semi-finals, and grand finals, (4) updates made by parties schools consist of evaluating the activities that have been carried out by finalists and evaluating the implementation of the program, (5) the characters that appear after the program implementation are that students pay more attention to the compilation teacher teaching, obeying the rules, (6) conducting visits, and providing school funding, (7) the solution carried out by the school is changing the schedule of visits, looking for sponsors
\end{abstract}

\section{Keywords: character education, character of the Putra Putri}

\begin{abstract}
Abstrak: Program Putra Putri Berkarakter sangat penting dilakukan agar manajemen pendidikan karakter dapat berjalan. Tujuan penelitian ini adalah mendeskripsikan kegiatan dari tahap perencanaan, pengorganisasian, pelaksanaan, evaluasi, kendala, dan solusi program Putra Putri Berkarakter. Penelitian ini menggunakan pendekatan kualitatif dengan jenis penelitian studi kasus. Proses pengumpulan data yang digunakan oleh peneliti yaitu observasi, wawancara, dan dokumentasi. Dalam analisis data, peneliti melakukan pengumpulan data, kondensasi data, sajian data, dan penarikan kesimpulan. Kesimpulan dari penelitian ini adalah (1) perencanaan program menghasilkan jadwal serta syarat dan ketentuan, (2) pengorganisasian program menghasilkan struktur organisasi, (3) pelaksanaan program meliputi tes tulis, tes wawancara, semi final, dan grand final, (4) evaluasi yang dilakukan pihak sekolah terdiri dari evaluasi mengenai kegiatan yang telah dijalankan oleh finalis dan evaluasi mengenai pelaksanaan program, (5) karakter yang tampak setelah pelaksanaan program adalah peserta didik lebih memperhatikan guru ketika sedang mengajar, taat peraturan, (6) kendala yang terjadi yaitu pergantian jadwal pelaksanaan kunjungan, dan penyediaan dana sekolah, (7) solusi yang dilakukan oleh sekolah yaitu mengganti jadwal kunjungan, mencari pihak sponsor.
\end{abstract}

Kata Kunci: pendidikan karakter, putra putri berkarakter

Pada hakikatnya pendidikan merupakan hal yang selalu dibutuhkan oleh masyarakat dari masa ke masa. Pendidikan disebut sebagai kebutuhan karena pada umumnya masyarakat juga memerlukan pendidikan untuk dapat terus mengikuti perkembangan zaman yang telah dilengkapi dengan teknologi yang sangat canggih. Pendidikan juga merupakan usaha yang dilakukan oleh manusia untuk senantiasa memperbaiki hidupnya. Pendidikan dilakukan oleh manusia secara sadar untuk membentuk pribadi yang tangguh dan 
berakhlak mulia. Menurut Sobri (2017:18) salah satu upaya pemerintah untuk memperbaiki kualitas pendidikan di Indonesia yakni dengan adanya gerakan penguatan pendidikan karakter di sekolah. Sekolah bukan sebuah tempat dimana seluruh persoalan bangsa bisa diselesaikan, namun menjanjikan banyak hal tentang perbaikan sebuah bangsa dimasa depan.

Berdasarkan penjelasan tersebut, pendidikan harus mampu menanamkan pengetahuan dan karakter yang mulia bagi siswa. Karakter juga merupakan perilaku yang ada pada diri manusia yang kerkenaan dengan sikapnya kepada dirinya sendiri maupun lingkungan sekitar. Dalam mewujudkan konsep pendidikan karakter tersebut diperlukan peran dari seluruh sistem pendidikan, sekolah, keluarga, dan masyarakat. Hal ini sesuai dengan pernyataan bahwa sistem pendidikan yang berhasil yaitu dapat membentuk manusia-manusia berkarakter yang sangat diperlukan dalam mewujudkan sebuah Negara kebangsaan yang terhormat (Megawangi, 2004).

Adapun beberapa faktor yang mempengaruhi pembentukan karakter seorang individu yaitu faktor lingkungan sekitar. Lingkungan yang memiliki kebiasaan baik akan mempengaruhi pembentukan karakter yang baik pada individu. Karakter yang baik tidak dapat tumbuh dengan sendirinya, karakter yang baik juga perlu ditumbuhkan dan dibentuk sejak dini pada seorang individu. Salah satu tempat pembentukan karakter bagi siswa adalah sekolah, karena sekolah sebagai lembaga pendidikan formal yang memiliki peran penting dalam pembentukan karakter individu. Sekolah juga merupakan tempat belajar dan berkembang. Hal ini sejalan dengan pendapat dari Darmayanti \& Wibowo (2014) bahwa untuk membentuk karakter pribadi yang matang diperlukan proses terus menerus dan berkesinambungan sepanjang kehidupan.

SMA Laboratorium Universitas Negeri Malang merupakan salah satu sekolah yang melaksanakan pendidikan karakter melalui program Putra Putri Berkarakter, yang dimana program tersebut termasuk dalam program humas. Program tersebut baru direalisasikan pada bulan November 2018 dan masih berlanjut hingga sekarang. Sekolah beranggapan bahwa penilaian terhadap peserta didik tidak hanya melalui penilaian secara akademik saja, namun bisa dilihat dari aspek keseharian mereka atau bisa disebut dengan karakter peserta didik. Dalam program pemilihan Putra Putri Berkarakrer ini sekokah hanya berfokus pada karakter peserta didik, tidak hanya melihat dari segi akademik maupun segi fashion saja. Program tersebut bertujuan untuk menghasilkan siswa yang unggul dalam berkarakter, memiliki moral, budi pekerti, dan dapat memberikan contoh terhadap peserta didik lainnya yang belum memunculkan karakter yang baik. Hal ini sesuai dengan pendapat dari Ardi, Sobri dan Kusumaningrum (2019:17) yang menyatakan bahwa moral dan budi pekerti merupakan pedoman hidup yang harus dimiliki seseorang agar terhalang dari pengaruh buruk lingkungan sekitar. Pernyataan tersebut juga sesuai dengan UndangUndang Republik Indonesia Nomor 20 tahun 2003 tentang Sistem Pendidikan Nasional Pasal 1 bahwa pendidikan merupakan suatu usaha secara sadar dan terencana untuk mewujudkan suasana belajar dan proses pembelajaran agar peserta didik dapat mengembangkan potensi dirinya secara aktif untuk memiliki kekuasaan spiritual keagamaan, pengendalian diri, kepribadian, kecerdasan, akhlak mulia, serta keterampilan yang diperlukan untuk dirinya, masyarakat, bangsa, dan Negara. Dalam program tersebut sekolah juga bekerja sama dan melakukan kunjungan ke Kang Yuk Kota Malang dan Dinas Pariwisata guna mendapatkan beberapa materi, seperti public speaking, pengetahuan singkat tentang Kota Malang.

Berdasarkan penelitian yang ditulis oleh Prihartoyo \& Dwiningrum (2014) bahwa manajemen pendidikan karakter di SMA De Britto berjalan sebagaimana mestinya. Direncanakan dengan matang melibatkan orang tua dan berpedoman pada visi misi, dilaksanakan dengan dinamis, dikontrol dan diawasi dengan tegas oleh pejabat yang ditunjuk, dan dievaluasi secara komprehensif melalui cara personalis, dan pendampingan. Penelitian lain yang ditulis oleh Panoyo, Riyanto, Handayaningrum (2019) menunjukkan bahwa, perencanaan penguatan pendidikan karakter harus memenuhi minimal lima aspek yaitu mengacu pada visi dan misi sekolah, melakukan asesmen untuk mengidentifikasi potensi sekolah, merumuskan dan menentukan nilai-nilai karakter utama yang akan dikembangkan, program sekolah disusun secara bersama seluruh komponen sekolah, serta guru pembuatan perangkat pembelajaran (RPP) berbasis karakter. 
Penelitian ini penting dilakukan untuk mengetahui manajemen pendidikan karakter dalam program Putra Putri Berkarakter, yang meliputi perencanaan, pengorganisasian, pelaksanaan, dan evaluasi. Hal ini sejalan dengan pendapat dari Purwanto (2008) bahwa dalam melakukan perencanaan terdapat beberapa langkah yang harus dilakukan yaitu menentukan dan merumuskan tujuan yang hendak dicapai, meneliti masalah-masalah yang akan dilakukan, mengumpulkan data dan informasi yang diperlukan, serta merumuskan bagaimana masalah-masalah itu akan dipecahkan. Penelitian ini berfokus pada karakter peserta didik dimana sekolah tidak melibatkan nilai akademik peserta didik, namun hanya melibatkan penilaian dari buku tata tertib yang dipegang oleh masing-masing peserta didik. Dari program tersebut diharapkan peserta didik memiliki karakter yang baik dan dapat memberikan contoh pada peserta didik lain yang belum memiliki karakter yang baik. Sehingga peneliti mengambil judul Manajemen Pendidikan Karakter Melalui Program Putra Putri Berkarakter di SMA Laboratorium Universitas Negeri Malang.

\section{METODE}

Pendekatan yang digunakan oleh peneliti yaitu kualitatif dengan jenis penelitian studi kasus. Lokasi yang peneliti gunakan yaitu di SMA Laboratorium Universitas Negeri Malang. Selanjutnya adalah menganalisis temuan penelian dengan menggunakan pengumpulan data, kondensasi data, sajian data, dan penarikan kesimpulan. Proses pengumpulan data yang digunakan oleh peneliti yaitu observasi, wawancara, dan dokumentasi. Data yang telah diperoleh akan diperiksa terlebih dahulu keabsahannya dengan cara: (1) Triangulasi sumber dimana peneliti juga melakukan wawancara dengan kepala sekolah, guru, dan peserta didik yang kemudian jawaban dari semua informasi dibandingkan untuk menemukan jawaban yang sama, selain itu peneliti juga menggunakan triangulasi teknik dengan membandingkan informasi dari kepala sekolah, guru, dan peserta didik melalui observasi, wawancara, dan dokumentasi, (2) Pengecekan Anggota yaitu memberikan hasil laporan hasil observasi kepada informan. Ketika hasil yang diberikan telah disetujui, peneliti meminta paraf dari informan sebagai bentuk persetujuan telah dilakukan peneliti, (3) Kecukupan Referensi, peneliti telah mengumpulkan bahan-bahan referensi yang dirasa cukup dalam menunjang penelitian, seperti transkip wawancara, catatan lapangan, dan foto-foto kegiatan program Putra Putri Berkarakter. Analisis yang dilakukan dalam penelitian ini bersamaan dengan pengumpulan data saat di lapangan. Dalam analisis data, peneliti melakukan pengumpukan data (data collection), kondensasi data (data condensation), sajian data (display data), dan penarikan kesimpulan (conclution drawing).

\section{HASIL DAN PEMBAHASAN}

Berdasarkan hasil penelitian mengenai manajemen program Putra Putri Berkarakter yang meliputi perencanaan, pengorganisasian, pelaksanaan, evaluasi, kendala pada pelaksanaan program, solusi mengatasi kendala, dan perubahan karakter yang timbul pada peserta didik, maka temuan penelitian ini dapat dilihat pada Gambar 1.

\section{Perencanaan Program Putra Putri Berkarakter}

Perencanaan program Putra Putri Berkarakter di SMA Laboratorium terdiri dari latar belakang atau alasan dilaksanakannya program, menentukan fungsi dan tujuan kegiatan, penetapan peraturan, waktu pelaksanaan, penganggaran, dana, dan syarat-syarat terkait pelaksanaan program. Hal ini didukung dengan pendapat dari Purwanto (2008) bahwa dalam melakukan perencanaan terdapat beberapa langkah yaitu menentukan dan merumuskan tujuan yang hendak dicapai, meneliti masalah-masalah yang akan dilakukan, mengumpulkan data dan informasi yang diperlukan, serta merumuskan masalah-masalah itu akan dipecahkan. Penjelasan ini sejalan dengan penelitian yang ditulis oleh Istiqamah (2018) berjudul bahwa Pondok Pesantren Al-Luqmaniyyah Yogyakarta menggunakan empat fungsi manajemen George R. Terry dalam melakukan pembinaan karakter santri, yang meliputi perencanaan, pengorganisasian, pengarahan, dan pengawasan. 


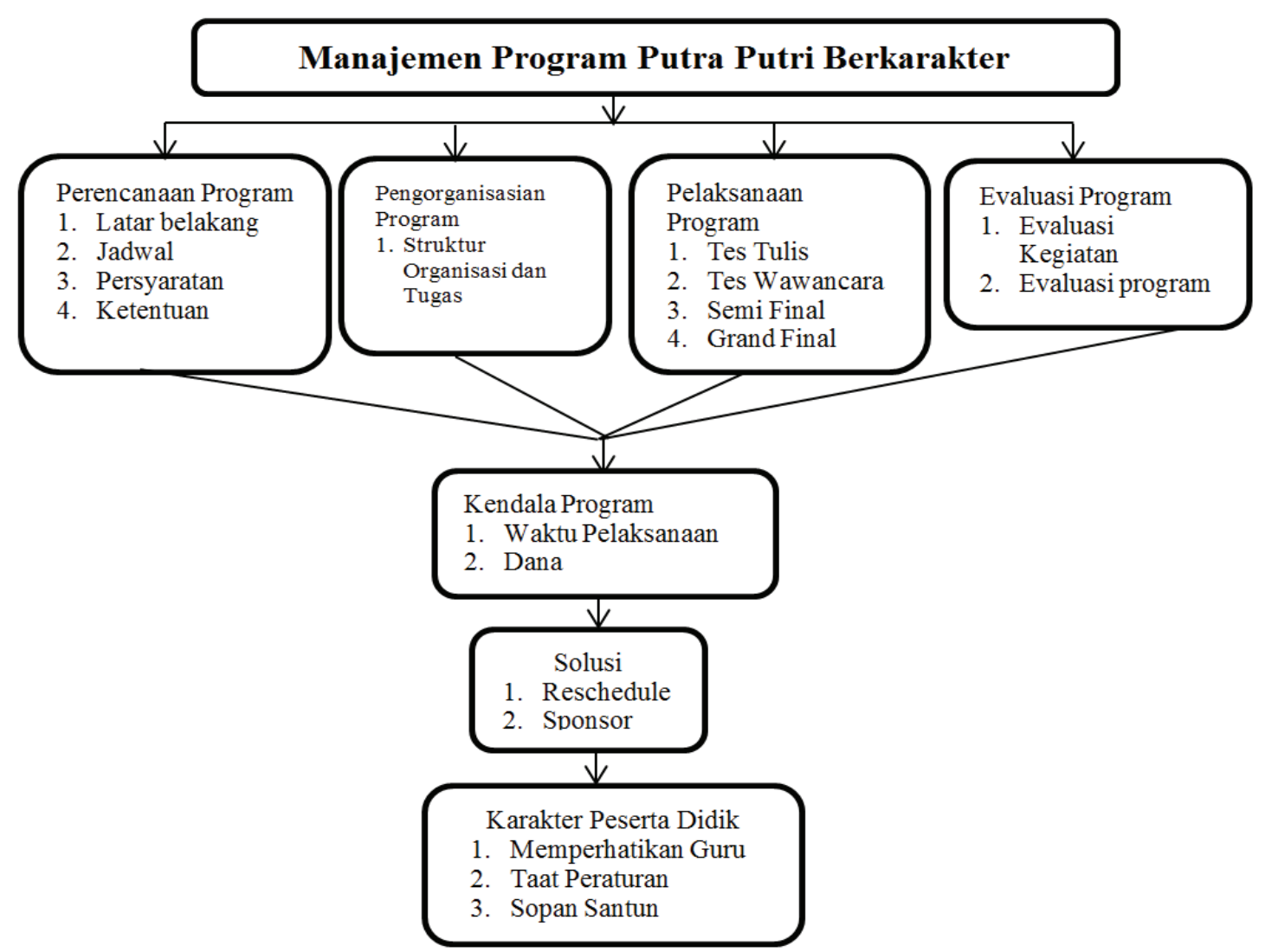

Gambar 1. Bagan Keseluruhan Temuan Penelitian

Adapun hal yang melatarbelakangi diadakannya program Putra Putri Berkarakter di SMA Laboratorium yaitu untuk mencetak karakter unggul, sesuai dengan tuntutan kurikulum, dan berangkat dari keprihatinan sekolah terhadap karakter siswa yang semakin menipis. Hal ini sejalan dengan pendapat dari Darmayanti \& Wibowo (2014) bahwa untuk membentuk karakter pribadi yang matang diperlukan proses yang terus menerus dan berkesinambungan sepanjang kehidupan. Proses ini harus dimulai sejak dini karena pada tahap perkembangan individu, usia dini anak adalah saat yang tepat untuk menanamkan nilai-nilai karakter, karena ini akan membentuk fondasi dasar untuk perkembangan selanjutnya agar nantinya anak tersebut memiliki moral dan budi pekerti pernyataan ini diperkuat dengan pendapat dari Ardi, Sobri dan Kusumaningrum (2019:17) yang menyatakan bahwa moral dan budi pekerti merupakan pedoman hidup yang harus dimiliki seseorang agar terhalang dari pengaruh buruk lingkungan sekitar. Pernyataan tersebut juga sesuai dengan Undang-Undang Republik Indonesia Nomor 20 tahun 2003 tentang Sistem Pendidikan Nasional Pasal 1 bahwa pendidikan merupakan suatu usaha secara sadar dan terencana untuk mewujudkan suasana belajar dan proses pembelajaran agar peserta didik dapat mengembangkan potensi dirinya secara aktif untuk memiliki kekuasaan spiritual keagamaan, pengendalian diri, kepribadian, kecerdasan, akhlak mulia, serta keterampilan yang diperlukan untuk dirinya, masyarakat, bangsa, dan negara.

Perencanaan program Putra Putri Berkarakter di SMA Laboratorium terdiri dari latar belakang/ alasan diadakannya program, menentukan fungsi program, waktu pelaksanaan, pihak-pihak yang bekerja sama, waktu pelaksanaan, penganggaran dana, persyaratan program, dan menentukan ketentuanketentuan program. Hal ini sesuai dengan pernyataan berdasarkan Jurnal yang ditulis oleh Supriyadi (2010) bahwa perencanaan kegiatan program pendidikan karakter di sekolah mengacu pada jenis-jenis kegiatan yang setidaknya memuat unsur-unsur. Hal ini juga didukung dengan pendapat Purwanto (2008) [8] bahwa dalam melakukan perencanaan terdapat beberapa hal yaitu tujuan, sasaran kegiatan, substansi kegiatan, pelaksanaan kegiatan dan pihak-pihak yang terkait, mekanisme pelaksanaan, keorganisasian, waktu dan tempat, serta fasilitas pendukung. 


\section{Pengorganisasian Program Putra Putri Berkarakter}

Pengorganisasian sangat penting dilakukan untuk memperjelas tugas, wewenang, dan tanggungjawab dari pihak-pihak yang terlibat dalam pelakanaan program Putra Putri Berkarakter. Hasil temuan yang didapatkan oleh peneliti di SMA Laboratorium proses pengorganisasian meliputi pembuatan struktu organisasi dan menentukan tugas dan wewenang. Hal ini sesuai dengan pendapat Purwanto (2008) bahwa proses pengorganisasian merupakan aktivitas menyusun dan membentuk hubungan kerja antara orang-orang sehingga terwujud suatu kesatuan usaha dalam mencapai tujuan yang telah ditetapkan. Pengorganisasian ini yang dianggap paling penting adalah adanya pembagian tugas, wewenang, dan tanggungjawab yang disesuaikan dengan pengalaman dan pengetahuan.

Berdasarkan temuan yang didapatkan oleh peneliti di SMA Laboratorium pengorganisasian program Putra Putri Berkarakter di SMA Laboratorium terdiri dari tiga tahapan. Ketiga tahapan itu adalah menentukan struktur organisasi, menentukan pihak yang akan bekerjasama atau sponsor yang mendukung kegiatan, dan melakukan sosialisasi kepada warga sekolah terutama peserta didik.

Pertama stuktur organisasi yang telah dibentuk oleh Wakil Kepala Sekolah selaku ketua pelaksana program harus disesuaikan yaitu dengan memilih guru yang berkenaan langsung mengenai karakter peserta didik seperti halnya guru Agama, PKn, dan BK. Hal yang menjadi pertimbangan adalah guru BK lebih mengetahui karakteristik diri seseorang dan guru PKn lebih mengetahui nilai-nilai moral sedangkan guru agama lebih mengetahui nilai akidah dan akhlak. Hal ini sejalan dengan pendapat dari Buchory dan Swadayani (2014) bahwa setiap program yang dilakukan sekolah harus melibatkan beberapa komponen sekolah, baik Kepala Sekolah, Wakil Kepala Sekolah, dan dan para guru dengan tugasnya masing-masing.

Kedua pihak sekolah juga melakukan kerja sama dengan pihak luar seperti Dinas Pariwisata, Kakang Mbakyu Kota Malang. Hal ini sesuai dengan pernyataan Wibowo (2013) yaitu pembagian kerja yang direncanakan untuk diselesaikan oleh kelompok kerja, dan pemberian fasilitas kerja yang sewajarnya supaya mereka dapat bekerja secara efisien.

Ketiga melakukan sosialisasi kepada warga sekolah terutama peserta didik. Dalam hal ini sekolah melakukan sosialisasi melalui koordinasi group whatsapp sekolah kepada wali kelas. Kemudian wali kelas memanggil ketua kelas, selanjutnya ketua kelas menyampaikan informasi kepada teman-temannya didepan kelas dan diakhiri dengan mengumpulkan peserta didik di halaman sekolah. Hal ini dilakukan sekaligus dalam memberikan edukasi kepada peserta didik untuk mampu menimbulkan perubahan dalam dirinya seperti pendapat dari Hamalik (2007:2) memberikan sosialisasi sekaligus edukasi dalam upaya untuk mempengaruhi peserta didik supaya mampu menyesuaikan diri dengan baik terhadap lingkungannya. Proses tersebut dapat menimbulkan perubahan dalam dirinya, maupun dalam kehidupan bermasyarakat.

\section{Pelaksanaan Program Putra Putri Berkarakter}

Pelaksanaan kegiatan merupakan salah satu inti dari sebuah manajemen, karena pelaksanaan merupakan implementasi dari suatu kegiatan yang telah disusun dan direncanakan sebelumnya. Berdasarkan hasil temuan yang didapatkan oleh peneliti terdapat enam tahapan dalam pelaksanaan program Putra Putri Berkarakter yaitu tahapan pelaksanaan, tahapan awal, tahap seleksi, menentukan dresscode, pemberian rewards, dan pengontrolan atau pengawasan terhadap dampak yang muncul dari pelaksanaan program Putra Putri Berkarakter.

Penggerakan adalah tugas penggerakan yang dilakukan oleh pimpinan, Oleh sebab itu kepemimpinan kepala daerah dan kepala sekolah sangat memiliki peran penting untuk menggerakkan para staf dalam menjalankan program kerja sekolah (Sagala, 2010:52). Tahapan di atas merupakan usaha sekolah dalam menggerakkan stafnya yakni Panitia program Putri Berkarakter di SMA Laboratorium.

Selama pelaksanaan program, sekolah melakukan pengawasan terhadap dampak yang muncul dari pelaksanaan program Putra Putri Berkarakter juga merupakan pengontolan apakah sudah sesuai dengan fungsi pendidikan karakter. Hal ini didukung dengan penjelasan lebih lanjut dari Gunawan (2012:30) tentang fungsi pendidikan karakter meliputi (1) dapat mengembangkan potensi diri 
memiliki hati yang baik, (2) dapat memperkuat dan membangun perilaku bangsa multicultur, (3) dapat meningkatkan beradaban bangsa yang kompetitif dalam pergaulan dunia.

Implementasi pendidikan karakter menurut (Supriyadi,2010) di sekolah dilaksanakan dalam dua kelompok kegiatan, yaitu terpadu dengan kegiatan pembelajaran, dan dengan kegiatan ekstrakulikuler. Berbagai hal yang terkait dengan karakter dimulai dengan pengenalan nilai secara kognitif, afektif, akhirnya ke pengenalan nilai secara nyata oleh peserta didik dalam kehidupan sehari-hari.

\section{Evaluasi Program Putra Putri Berkarakter}

Penilaian pendidikan karakter menurut Wibowo (2013) harus disesuaikan dengan pedoman penilaian Penguatan Pendidikan Karakter (PPK) yang dilakukan oleh kepala sekolah (internal) dan beberapa pihak sekolah (eksternal). Dalam hal ini sekolah masih berupaya dalam mewujudkannya untuk sesuai dengan pedoman penilaian PPK. Dalam program yang dijalankan sekolah ini, kesesuaian dengan rencana program ini yaitu sudah sesuai akan tetapi masih belum sempurna, kemudian program ini akan diadakan secara berkelanjutan, dan mempersiapkan lagi lebih matang.

Pernyataan sekolah di atas sesuai pula dengan pernyataan (Usman, 2011:66) tentang planning yang merupakan proses dalam pengambilan keputusan atas beberapa alternatif mengenai sasaran dan beberapa cara yang akan dilaksanakan guna mencapai tujuan yang telah ditetapkan sebelumnya, serta melakukan penilaian atas hasil dari pelaksanaan yang dilakukan secara sistematis dan berkesinambungan.

Waktu evaluasi yang dilakukan yaitu seminggu sekali (jika diperlukan), ada evaluasi kegiatan dan evaluasi program, kemudian untuk mempermudah koordinasi menggunakan group whatsApp. Kemudian pihak yang terlibat dalam evaluasi yaitu kepala sekolah, ketua pelaksana (waka humas), panitia, dan wali kelas. Berdasarkan pernyataan tersebut maka yang dilakukan oleh sekolah merupakan evaluasi/penilaian internal. Pendapat Wibowo (2013) menguatkan bahwa penilaian internal dilakukan oleh warga sekolah yang terdiri dari kepala sekolah, guru, wali murid, dan komite sekolah. Sedangkan dalam penilaian secara eksternal dilakukan oleh pihak-pihak luar sekolah yang berkepentingan untuk bersama-sama menyukseskan pelaksanaan program PPK.

Hasil yang dicapai yaitu adanya progres dari buku tata tertib, finalis lebih disiplin dan berani, memiliki good attitude dan menjadi contoh. Kelima, program Putra Putri Berkarakter yaitu bagi-bagi takjil, morning motivation, membantu penerima raport, menjadi penerima tamu sekolah, menjadi MC acara sekolah, jumat bersih, dan mengikuti event di luar sekolah. Hasil tersebut dapat dimaknai bahwa sekolah berhasil dalam mencapai tujuan pendidikan dan penguatan karakter. Hal ini sesuai dengan pendapat dari (Megawangi dalam Gunawan, 2012:30) pendidikan karakter bertujuan untuk mengukir akhlak melalui proses knowing the good, loving the good, and acting the good, yaitu sebuah proses pendidikan yang melibatkan beberapa aspek yang meliputi kognitif, emosi, dan fisik, sehingga akhlak mulia dapat terukir dalam diri individu menjadi habit of the mind, heart, and hands.

Hasil Monitoring dan evaluasi dari implementasi program pembinaan pendidikan karakter Menurut (Supriyadi:2010) digunakan sebagai acuan unruk menyempurnakan program, mencakup penyempurnaan rancangan, mekanisme pelaksanaan, dukungan fasilitas, sumber daya manusia, dan managemen sekolah yang terkait dengan implementasi program. Berdasarkan pernyataan tersebut maka SMA Laboratorium Universitas Negeri Malang dalam pelaksanaannya sudah sesuai, yakni menggunakan hasil evaluasi sebagai bahan untuk menjalankan program serupa selanjutnya dengan melakukan perbaikan-perbaikan sesuai saran dan masukan dari keseluruhan panitia yang terlibat di dalamnya.

\section{Karakter yang Tampak Terhadap Peserta Didik Setelah Adanya Program Putra Putri Berkarakter}

Karakter yang tampak pada Putra Putri Berkarakter di SMA Laboratorium adalah adanya perubahan karakter, semakin memperhatikan dan menaruh perhatian kepada guru, memiliki disiplin yang tinggi, menjadi lebih taat lagi pada aturan, dan memiliki rasa saling peduli. Hal ini juga diperkuat dengan pendapat dari Suradi (2017:524) yaitu jika dikaitkan dengan dunia pendidikan, karakter siswa yang baik adalah karakter siswa yang menunjukkan bahwa dirinya seorang pelajar yang berpendidikan. 
Anak yang terpelajar dan terdidik melalui proses pembelajaran dan pendidikan yang baik tentu saja akan menghasilkan anak yang berkarakter baik. Mereka akan mempunyai watak yang jujur, disiplin, bertanggung jawab, sopan santun, peduli terhadap orang lain, tidak sombong, mampu menghargai karya orang lain, memiliki daya kreatif tinggi. Peserta didik menurut (Supriyadi,2010) cenderung akan belajar dan meniru perilaku orang-orang yang ada di sekitarnya. Faktor terpenting dari keberhasilan pendidikan karakter di sekolah adalah guru atau warga sekolah secara keseluruhan yang selalu berperilaku sebagai model pribadi yang pantas ditiru setiap saat. Hal ini sesuai dengan hasil yang didapatkan dari penelitian di lapangan yakni dalam proses pembelajaran maupun diluar proses pembelajaran, finalis Putra Putri Berkarakter bereran sebagai model atau contoh untuk memberikan keteladanan dan attitude baik kepada teman-temannya. Berdasarkan keteladanan tersebut terbukti bahwa peserta didik cenderung lebih suka meniru perilaku teman-teman finalis Putra-Putri Berkarakter untuk menanamkan karakter mereka pula baik di dalam kelas maupun di luar kelas.

\section{Kendala dalam Pelaksanaan Program Putra Putri Berkarakter}

Kendala dalam pelaksanaan program Putra Putri Berkarakter di SMA Laboratorium terdiri dari tiga kendala. Ketiga kendala tersebut yaitu sekolah sulit mencari pihak yang mau untuk diajak bekerja sama, kemudian sulit mensinkronkan waktu dengan pihak yang diajak bekerjasama karena sering ada kegiatan atau urusan mendadak, dan ketika ada mendadak sekolah harus sering melakukan penjadwalan ulan (reschedule) dengan pihak yang diajak bekerjasama. Sesuai dengan teori Ubaidah (2012) yang menyatakan bahwa penjadwalan merupakan salah satu kegiatan administrasi di sekolah. Jadwal dimaksudkan untuk mengatur program belajar, praktik, program lapangan dapat terselenggara secara tertib sesuai dengan ketentuann yang berlaku dengan memenfaatkan seluruh sumber daya yang tersedia dengan segala keterbatasan.

Uraian kendala diatas merupakan kendala yang mampu membentuk atau melatih peserta didik dan pihak yang bersangkutan untuk memperkuat karakter dalam menghadapi kenyataan. Hal ini sesuai dengan pernyataan dari Samani (2012:43), karakter dapat dimaknai sebagai nilai dasar yang dapat membangun kepribadian seseorang, dapat terbentuk baik akibat factor hereditas maupun juga dari pengaruh lingkungan sekitar, yang membedakannya dengan orang lain, dan dapat diwujudkan dalam sikap dan kegiatan sehari-hari dalam bermasyarakat.

\section{Upaya Mengatasi Kendala pada Pelaksanaan Program Putra Putri Berkarakter}

Dalam hal ini uapaya yang dilakukan yaitu melakukan pergantian jadwal dan melakukan koordinasi ulang kepada pihak yang diajak bekerjasama. Sedangkan upaya untuk mengatasi kendala pada program yaitu dengan melakukan konsultasi dengan BK, mencari dan menemukan solusi, dan lebih bersabar dan lebih menambah kepekaan lagi. Sedangkan upaya untuk kendala selanjutnya adalah mencari sponsor untuk menambah kekurangan dana dari sekolah agar sekolah dapat melaksanakan program Putra Putri Berkarakter yang cukup besar.

Upaya yang dilakukan oleh sekolah di atas merupakan keputusan yang tepat sekaligus dapat memberikan pendidikan karakter eksternal dari diri peserta didik. Hal ini sebagaimana pernyataan dari Megawangi (2004:95) yaitu sebuah usaha untuk mendidik anak-anak agar dapat mengambil keputusan dengan bijak dan untuk memperaktikkan dalam kehidupan sehari-hari, sehingga mereka dapat memberikan kontribusi yang positif terhadap lingkungan.

\section{SIMPULAN DAN SARAN}

\section{Simpulan}

Kesimpulan dari penelitian ini terdiri dari: (1) perencanaan program Putra Putri Berkarakter yaitu melihat latar belakang, menentukan jadwal pelaksanaan, menentukan peraturan, menentukan persyaratan, dan kententuan program, yang dimana diambil dari kesepakatan bersama paniti pelaksana (2) pengorganisasian pogram Putra Putri Berkarakter yaitu menentukan struktur organisasi beserta tugas dan wewenang. Beberapa guru juga terlibat dalam pelaksnaaan program ini, (3) pelaksanaan program 
Putra Putri Berkarakter meliputi tes tulis, tes wawancara, babak semifinal, dan babak grand final. Pelaksanaan kegiatan tersebut dilakukan dalam sekolah dan luar sekolah, (4) evaluasi program Putra Putri Berkarakter terdapat dua jenis evaluasi yaitu evaluasi terhadap kegiatan dan evaluasi mengenai program Putra Putri Berkarakter yang dimana semua panitia ikut dalam pelaksanaan evaluasi, (5) karakter yang tampak terhadap peserta didik setelah pelaksanaan program Putra Putri Berkarakter yaitu karakternya berubah menjadi lebih baik contohnya saja seperti adanya perubahan karakter pada peserta didik, semakin memperhatikan dan menaruh perhatian kepada guru saat pembelajaran di dalam kelas, memiliki disiplin yang tinggi, menjadi lebih taat lagi pada aturan yang telah ditetapkan sekolah, dan memiliki rasa saling peduli antara sesama teman, (6) kendala yang terjadi dalam pelaksanaan program Putra Putri Berkarakter yaitu pada waktu pelaksanaan kegiatan kunjungan yang berubah, dan anggaran dana sekolah, dan (7) solusi dari kendala yaitu melakukan pergantian jadwal kegiatan (reschedule) dan mencari pihak sponsor.

\section{Saran}

Berdasarkan hasil penelitian, saran diberikan kepada beberapa pihak antara lain sebagai berikut: (1) Kepala SMA Laboratorium Universitas Negeri Malang dapat mencatat aspek perubahan karakter dan menentukan standar karakter yang harus dicapai berikutnya sehingga dapat meningkatkan kualitas dan mutu karakter peserta didik; (2) Guru di SMA Laboratorium Universitas Negeri Malang melakukan monitoring terhadap peserta didik agar mengetahui bagaimana perkembangan karakter dan keberhasilan progam tersebut; (3) Peserta didik dapat memahami hasil evaluasi yang diberikan oleh pihak sekolah untuk meningkatkan kualitas dan keberhasilan program yang ada agar sesuai keinginan pihak sekolah; (4) Peneliti lain dapat mengukur seberapa besar dampak karakter yang tercipta baik dari standar yang telah ditentukan sekolah maupun kecenderungan karakter yang dimiliki peserta didik, karena karakter peserta didik yang dimiliki berbeda-beda dan tidak bisa disamaratakan.

\section{DAFTAR RUJUKAN}

Agus, W. Manajemen Pendidikan Karakter di Sekolah. Yogyakarta: Pustaka Pelajar, 2013.

Ardi, NSP. Sobri, AY, dan Kusumaningrum, DE. 2019. Manajemen Pembinaan Akhlak dalam Penguatan Pendidikan Karakter Peserta Didik. Vol 2 No. 1, (Online), (http://journal2.um.ac.id/index.php/jamp), diakses 22 Juni 2019.

Darmayanti, S.E. \& Wibowo, U.B. 2014. Evaluasi Program Pendidikan Karakter Di Sekolah Dasar Kabupaten Kulon Progo, 2(2), 224. Dari https://journal.uny.ac.id/index.php/jpe/article/view/2721/2271.

Gunawan, H. 2012. Pendidikan Karakter: Konsep dan Implementasi. Bandung: Alfabeta.

Hamalik, O. Manajemen Pengembangan Kurikulum. 2006.

Megawai, R. 2004. Pendidikan Karakter: Solusi yang Tepat untuk Membangun Bangsa. Bogor: Indonesia Hiterage Foundation.

Nachrowi, D dan Usman, H. Teknik Pengambilan Keputusan. Grasindo, 2004.

Panoyo, P, Riyanto, Dkk. Manajemen Penguatan Pendidikan Karakter Pada Sekolah Menengah Atas. Halaqa Islam Educ. J., Vol 3 No 2, hlm. 111-117, 2020.

Prihantoyo, Y. R dan Dwinngrum, S. I. A. Manajemen Pendidikan Karakter di SMA De Britto. Yogyakarta. J. Akuntabilitas Manajemen Pendidikan. Vol 2 No 1, hlm. 135-146, 2014.

Purwanto, N. 2008. Dasar-Dasar Ilmu Pendidikan. Yogyakarta: Ar-Ruzz Media

Samani, Muchlas \& Hariyanto. 2012. Pendidikan Karakter. Bandung: PT Rosdakarya.

Sukemi, B.M \& Swadayani, T.B. 2014. Implementasi Program Pendidikan Karakter di SMP, IV(3). Dari https:// journal.uny.ac.id/index.php/jpka/article/view/5627.

Supriyadi, E. 2010. Pengembangan Pendidikan Karakter di Sekolah. Staffnew.uny.ac.id diakses pada 9 September 2019.

Suradi. 2017. Pembentukan Karakter Siswa melalui Penerapan Disiplin Tata Tertib Sekolah, 2(4), 524. Dari https://www.researchgate.net/publication/321041635_Pembentukan_Karakter_Siswa_melalui_Penerapan Disiplin_Tata_Tertib_Sekolah.

Sobri, A.Y. 2017. Manajemen Pendidikan Karakter Berbasis Religi Di Sekolah Dasar. (Online), (http://journal2. um.ac.id/index.php/jamp), diakses pada 21 Oktober 2019. 